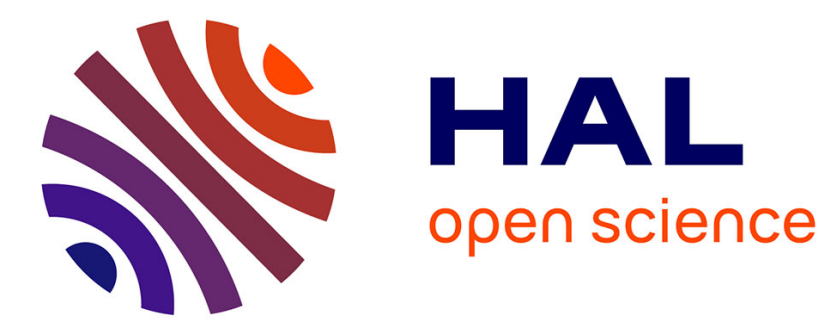

\title{
The Polyx photovoltaic technology: progress and prospects
}

\author{
J. Fally, E. Fabre, B. Chabot
}

\section{To cite this version:}

J. Fally, E. Fabre, B. Chabot. The Polyx photovoltaic technology: progress and prospects. Revue de Physique Appliquée, 1987, 22 (7), pp.529-534. 10.1051/rphysap:01987002207052900 . jpa-00245572

\section{HAL Id: jpa-00245572 https://hal.science/jpa-00245572}

Submitted on 1 Jan 1987

HAL is a multi-disciplinary open access archive for the deposit and dissemination of scientific research documents, whether they are published or not. The documents may come from teaching and research institutions in France or abroad, or from public or private research centers.
L'archive ouverte pluridisciplinaire HAL, est destinée au dépôt et à la diffusion de documents scientifiques de niveau recherche, publiés ou non, émanant des établissements d'enseignement et de recherche français ou étrangers, des laboratoires publics ou privés. 


\title{
The Polyx photovoltaic technology : progress and prospects
}

\author{
J. Fally $(*)$, E. Fabre $\left({ }^{* *}\right)$ and B. Chabot $\left({ }^{* * *}\right)$ \\ (*) Ingénieur aux Laboratoires de Marcoussis \\ (**) Directeur scientifique et technique à Photowatt \\ $\left.{ }^{* * *}\right)$ Ingénieur à l'AFME, av. E.-Hugues, 06565 Valbonne Cedex, France
}

(Reçu le 6 octobre 1986, accepté le 13 avril 1987)

\begin{abstract}
Résumé. - Parmi les multiples filières photovoltaïques qui sont envisageables, la filière silicium multicristallin obtenue par moulage de lingots, connue en France sous le nom de «procédé Polyx », est une des plus prometteuses du fait des performances industrielles déjà obtenues et des potentialités importantes d'évolution en coûts et rendements de conversion énergétique. Le procédé d'élaboration des lingots de silicium multicristallin à partir de charges de silicium polycristallin est décrit ainsi que la technologie de découpage en plaques minces et la réalisation de cellules et modules. Les rôles respectifs de la recherche de base aux Laboratoires de Marcoussis de la CGE et de la recherche et développement en milieu industriel chez Photowatt sont analysés. Une évaluation des coûts et prix des modules, des générateurs et du prix du $\mathrm{kWh}$ actuels et futurs obtenus avec ce procédé est présentée. Les applications et marchés photovoltaïques pour laquelle cette filière est la mieux adaptée sont décrits et analysés, y compris sous l'aspect des transferts de technologie.
\end{abstract}

\begin{abstract}
The so-called French « Polyx process » based on moulded multicrystalline silicon ingots is one of the most promising photovoltaic technologies due to its present industrial state and its possible improvements related to costs and conversion efficiency. Multicrystalline ingot processing from polycrystalline feedstock silicon, wafers, cells and module processing are described. Respective rôles of basic research at Laboratoires de Marcoussis of CGE and of industrial R \& D at Photowatt are analysed. An estimate of costs and prices is given for modules, systems and energy produced both for present and for future state of development of this technology. A description and an analysis of photovoltaic markets well suited to this technology are given, including technology transfer.
\end{abstract}

\section{Introduction.}

The major photovoltaic technologies in current use or under development are based on crystalline silicon or on thin layers of amorphous hydrogenated silicon. Approximately three quarters of the 20 peak MW of photovoltaic modules sold in 1985 used crystalline silicon for so called « energy-related » applications (from a few peak watts to peakMegawatts), while the remaining quarter used amorphous hydrogenated silicon for so-called « micro » and « mini » power requirements ranging between a few microwatts to a few peak watts, mainly related to pocket calculators. Although two out of three crystalline silicon modules are still using monocrystalline silicon cells, there is a rapid growth of the market share of « multicrystalline technology » currently used in Europe, the USA and Japan.
In France, such a technology, called the « Polyx process » is currently being marketed by Photowatt, after having had the benefit of substantial support given to the research and development programs of the CGE Marcoussis Laboratories (originators of the process) and of Photowatt through the photovoltaic plan developed and implemented by COMES and then by AFME, to which many CNRS and university laboratories also contributed. After a description of the present state of progress of the process, prospects for improvement and possible outlets will be examined.

\section{Description of the Polyx process and current results.}

Broadly, the process involves making multicrystalline silicon ingots from polycristalline silicon of the 


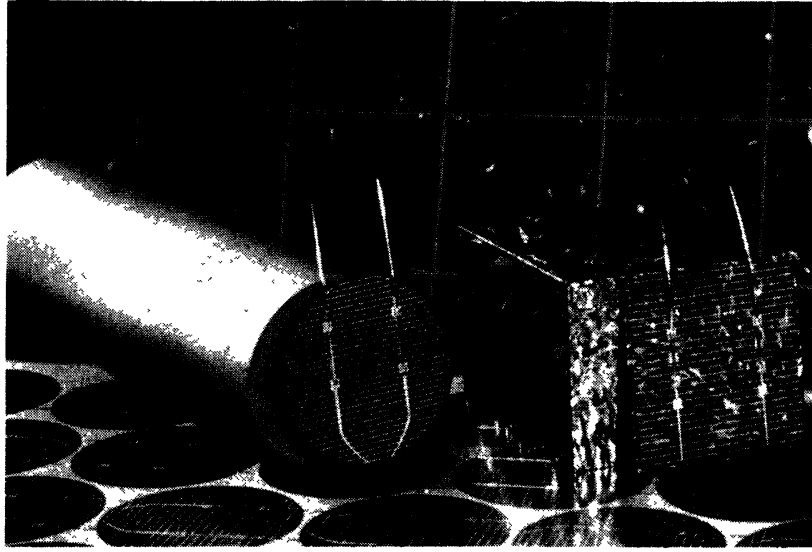

Photo 1. - Mono and multicrystalline ingots, cells and modules.

so-called «electronic off-grade " or «solar-grade » qualities, then sawing these large ingots into $10 \mathrm{~cm}$ sided bricks, followed by wafering into thin wafers, making cells on these wafers and, finally, their encapsulation into modules. Photograph 1 shows the appearance of multicrystalline silicon bricks, wafers, cells and modules alongside the same components in monocrystalline silicon (round shapes). We now propose to concentrate on the original feature of the process : i.e. the production of ingots through directional crystallisation controlled in a liquid encapsulation crucible which, through an original method of ingot extraction, allows the crucible to be re-used.

Figure 1 shows the underlying principle of the moulding and crystallization process. It was the increased ingot size which was the most marked feature of the successive furnaces developed. In 1980 , at the outset, the first furnace constructed by Marcoussis Laboratories handled 0.5 to $2 \mathrm{~kg}$ ingots. Since ingot size is a critical parameter in increasing

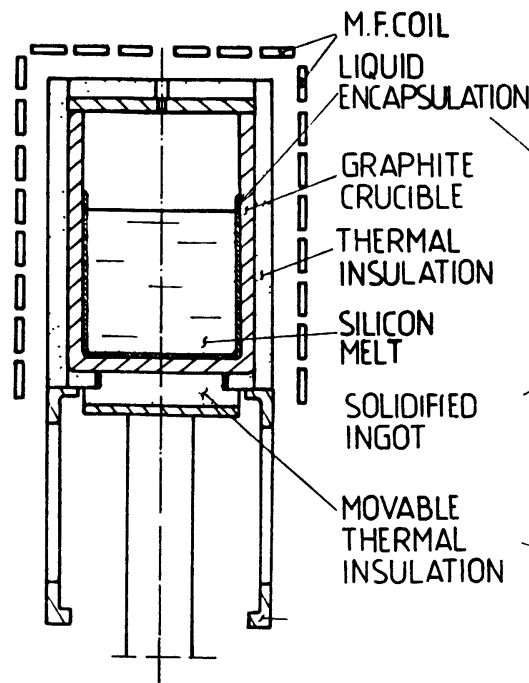

MELTING

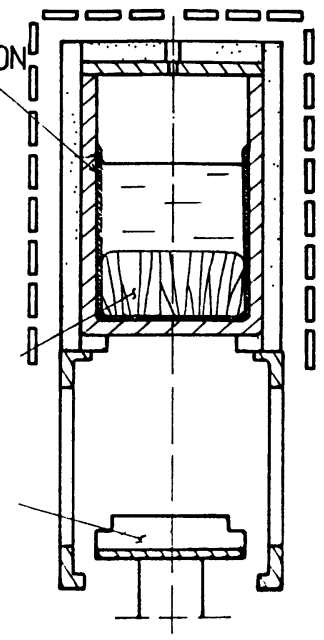

CRYSTALLIZATION
Fig. 1. - Crystallization method.

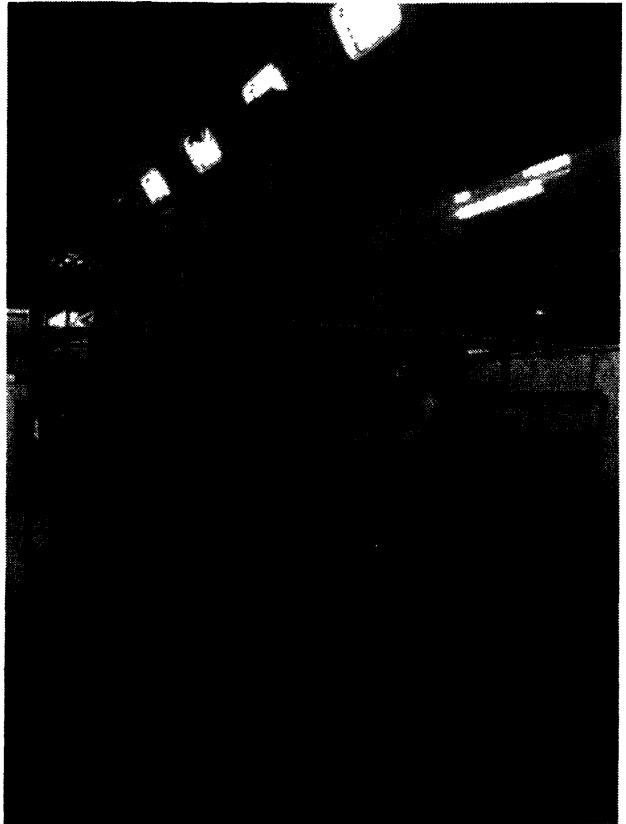

Photo 2. - Industrial $50 \mathrm{~kg}$ polyx ingot casting furnace.

final quantities of usable materials and in achieving required productivity, the Marcoussis Laboratories then designed and produced a furnace which could cast $20 \mathrm{~kg}$ ingots. The major parameters of the

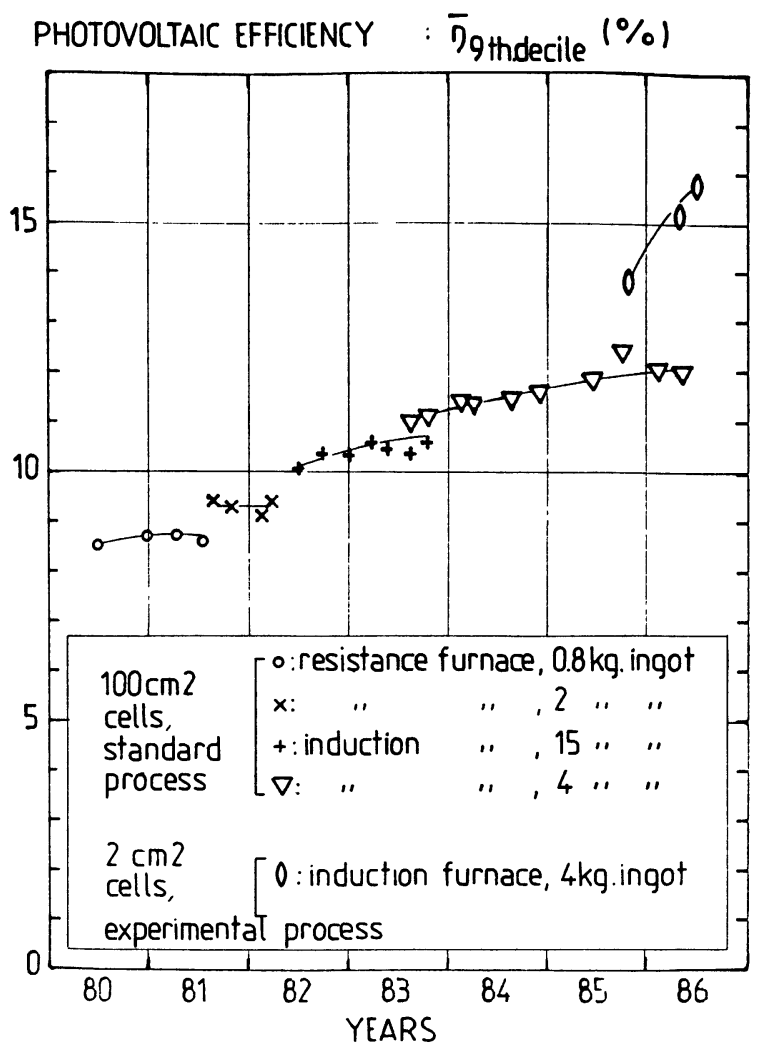

Fig. 2. - Trend of photovoltaic efficiencies obtained on Polyx materials. 
process were then optimized in this furnace, which was then transferred to Photowatt in 1983 and, on the basis of the experience acquired with these R\&D furnaces, the first industrial pilot furnace was designed by Photowatt and became operative at the end of 1984 (see photograph 2). Industrial production began in 1985 and should rapidly expand.

Figure 2 summarises the most significant parameters of the process developed by Marcoussis Laboratories : it should particularly be noted that a photovoltaic efficiency of more than $12.5 \%$ was obtained on $100 \mathrm{~cm}^{2}$ cells produced by the Photowatt standard process from multicrystalline silicon ingots moulded by Marcoussis Laboratories from electronic off-grade silicon.

Moreover, trials using silicon of varying origin and quality showed it was possible to define the chemical specifications of polycrystalline silicon suitable for producing ingots to be used to make photovoltaic cells with a specified average efficiency rating. Table I gives specification limits for final photovoltaic efficiency greater than $11.5 \%$. It has also been possible to quantify the effects of impurities on Polyx wafers and figure 3 shows the effect of such impurities on cells efficiency.

Cooperation between Marcoussis Laboratories and Photowatt resulted in a rapid shift to industrial production. Thus, figure 4 shows trends in photovoltaic efficiency achieved in 1985 with large ingots (with a mass greater than $50 \mathrm{~kg}$ permitting sawing into $10 \times 10 \mathrm{~cm}$ sided bricks). Average photovoltaic efficiency is now above $10.5 \%$ and some ingots have average efficiency of more than $11 \%$, with cells going over $12 \%$ under standard manufacturing conditions. Additionally, the requirements of industrial production led Photowatt to make substantial efforts to optimise the process and apply appropriate technical solutions such as ingot extraction on an industrial

Table I. - Silicon chemical specifications to obtain JSC $\geqslant 27$ MA/CM2 $(\bar{n}>11.5 \%)$ on $90 \%$ of the heigth of Polyx ingots (current process).

\begin{tabular}{|c|c|c|c|c|}
\hline Elements & $\begin{array}{c}\text { Permissible content } \\
\text { in wafers } \\
\left(\mathrm{At} / \mathrm{cm}^{3}\right)\end{array}$ & $\begin{array}{l}\text { Permissible content } \\
\text { in wafers } \\
\text { (ppmA) }\end{array}$ & $\begin{array}{c}\text { Permissible content } \\
\text { in charge } \\
(\mathrm{ppmA})\end{array}$ & $\begin{array}{c}\text { Permissible content } \\
\text { in charge } \\
\text { (ppm.weight) }\end{array}$ \\
\hline $\mathrm{Al}$ & 3 E 16 & 0,6 & 3 & 2,88 \\
\hline B & 9 E 15 & 0,18 & 0,156 & 0,06 \\
\hline $\mathrm{Ga}$ & 7 E 14 & 0,014 & 0,175 & 0,43 \\
\hline In & 7 E 14 & 0,014 & 0,35 & 1,45 \\
\hline $\mathbf{P}$ & 7 E 14 & 0,014 & 8,4 E-3 & $9,8 \mathrm{E}-3$ \\
\hline As & 7 E 14 & 0,014 & $9,1 \mathrm{E}-3$ & 0,021 \\
\hline $\mathrm{Sb}$ & 7 E 14 & 0,014 & 0,038 & 0,168 \\
\hline $\mathrm{Cu}$ & 7 E 15 & 0,14 & 2,8 & 6,35 \\
\hline $\mathrm{Cr}$ & $2,5 \mathrm{E} 14$ & $5 \mathrm{E}-3$ & 1,65 & 3,05 \\
\hline $\mathrm{Fe}$ & $6 \mathrm{E} 14$ & 0,012 & 8,53 & 17 \\
\hline $\mathrm{Ni}$ & 1,2 E 17 & 2,4 & 50,5 & 105,5 \\
\hline Mo & $1 \mathrm{E} 13$ & $2 \mathrm{E}-4$ & 0,21 & 0,73 \\
\hline $\mathrm{Zr}$ & $4 \mathrm{E} 14$ & $8 \mathrm{E}-3$ & 3,3 & 10,82 \\
\hline $\mathrm{C}$ & $5 \mathrm{E} 17$ & 10 & 73 & 31 \\
\hline $\mathrm{O}$ & $6 \mathrm{E} 17$ & 12 & 270 & $154^{\circ}$ \\
\hline
\end{tabular}




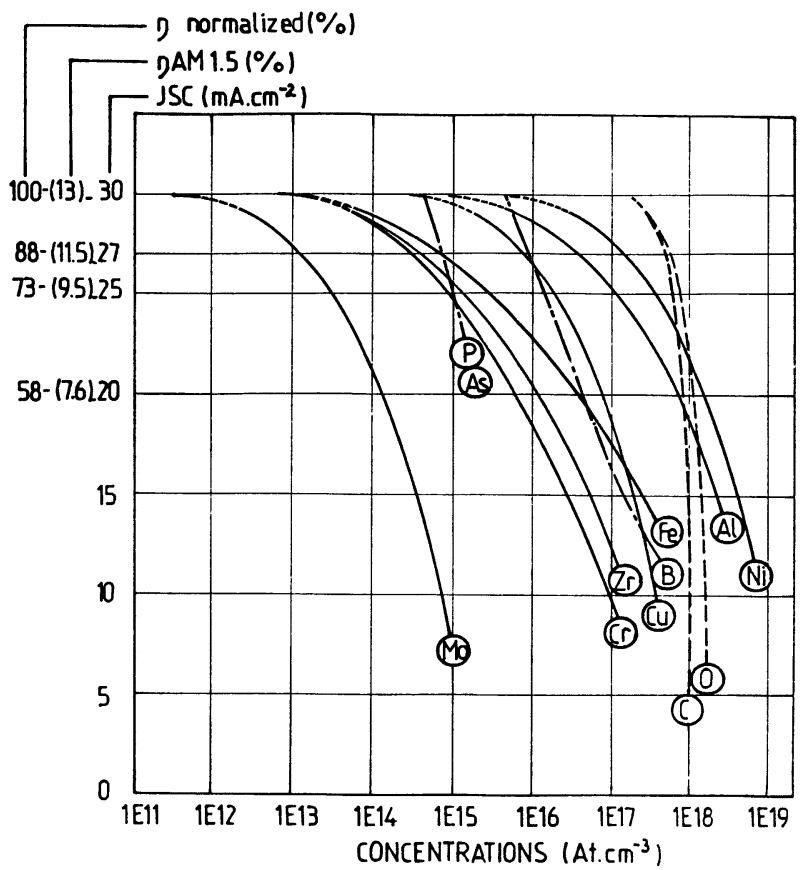

Fig. 3. - Influence of impurities in Polyx wafers on the photovoltaic parameters.

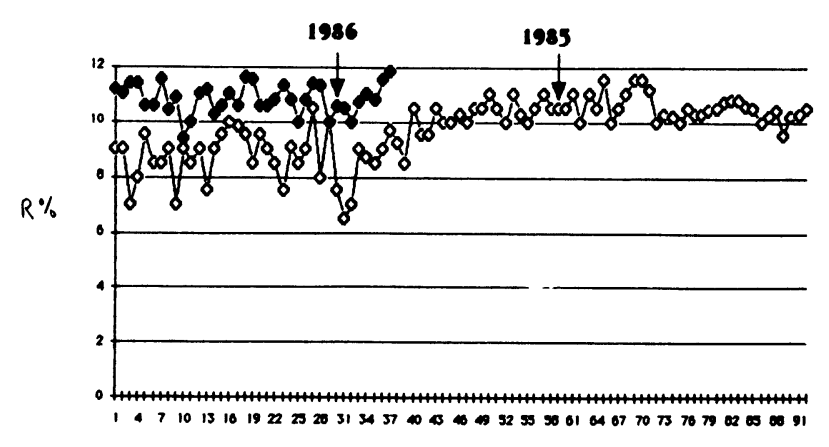

InCOT MUMEE ALONG THE TEAR

Fig. 4. - Mean photovoltaic efficiency.

scale, reduction of the complete cycle time to under 20 hours, study of continuous reloading of silicon, optimisation of graphite crucible, testing and manufacturing of liquid encapsulators first formulated and developed by Marcoussis Laboratories.

In addition by 1984, Photowatt had already initiated a development program for sawing bricks into wafers with wire saws, thus substantially reducing required quantities of silicon by influencing both the thickness of the sawn wafers and the reduction of losses of material in the wafering process, applying not only to kerf-loss width but also to a reduction of layer disturbance and of wafering shrinkage. This cost reduction factor is enhanced by increased productivity and it is thus possible to achieve cell thicknesses of less than 400 microns with kerf-losses of less than 170 microns under standard production conditions, with production of 350 wafers in $5 \mathrm{~h}$. Recent trials have shown that it is possible to saw 150 microns wafers with these wire saws and to manufacture cells and modules from these materials.

\section{Development prospects for the Polyx process.}

The process is far from frozen and has extensive development potential. For instance, photovoltaic efficiency obtained under manufacturing conditions will probably rise to close to $14 \%$ by 1990 and Marcoussis Laboratories have already achieved efficiency levels of over $15 \%$ on the total area of $2 \times 1 \mathrm{~cm}$ cells. Moreover, optimization of the process with particular regard to crystalline growth conditions resulting in directional segregation of impurities should make it possible to use initial silicon which is both less pure and less expensive.

In the long run, the use of inexpensive improved metallurgical grade could become possible. In this connection, mention should be made of the starting purification of the material by a plasma process developed by ENSCP and under current technical and economical evaluation by Photowatt. Substantial improvements in productivity can also be obtained by reducing the duration of manufacturing cycles and by increasing ingot size, in order to produce up to $120 \mathrm{~kg}$ of ingots per day and per furnace. Since the reduction of cell thickness and of kerf-loss due to the use of wire saws will diminish the quantity of silicon needed to produce a cell, a single moulding equipment will be able to produce more than 2 peak MW per annum. Finally, cell and module production will be able to benefit from improvements in low-cost processes such as the generalised use of silk-screen printing which should, additionally, facilitate greater automation.

\section{Economic aspects.}

Figure 5 shows the development of existing and forecast direct manufacturing costs of monocrystalline and multicrystalline silicon photovoltaic modules for two periods : 1986 and 1990, with reference to "monocrystalline silicon " with associated purchase of corresponding monocrystalline wafers in the mar-

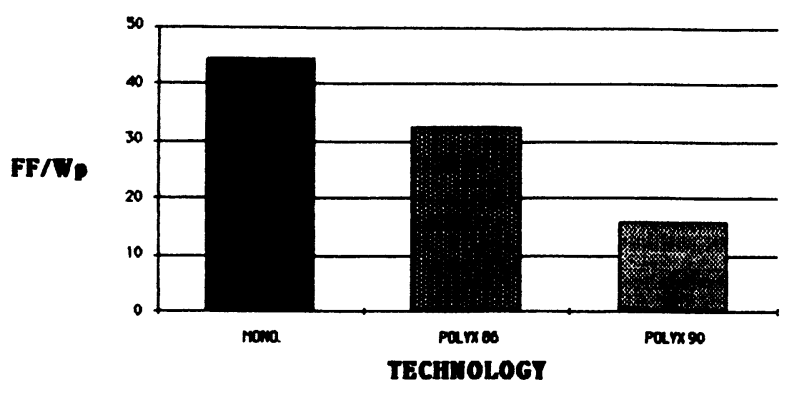

Fig. 5. - Modules manufacturing costs. 
ket. The comparison, relating to units which have a capacity close to 1 peak MW per annum, is based on a computer program for comparing photovoltaic technologies developed by AFME with the cooperation of industry for the provision of cost data.

It can be seen that the marked reduction in costs experienced in shifting from current monocrystalline to multicrystalline silicon will be further enhanced when the entire above-mentioned potential of the Polyx process has been fulfilled.

For photovoltaic generators to be used for common practical applications in the next few years, such as telecommunications and the electrification of remote areas and communities, price reductions of related systems will be partly offset by the influence of far more static costs of non-photovoltaic elements such as storage batteries, switchgear and electromechanical equipment and of the infrastructure such as module support, cabling and the relevant civil engineering works. $\mathrm{Be}$ that as it may, the price reductions are substantial and, in particular, if compared with the direct cost of similar modules, are more marked than for modules based on a technology which does not produce such a high module-related photovoltaic efficiency, i.e. $10 \%$ currently and $13.5 \%$ in the medium term. In actual fact, as is shown in figure 6 , the relative weighting of proportional cost lines to the area of modules installed is no longer marginal.

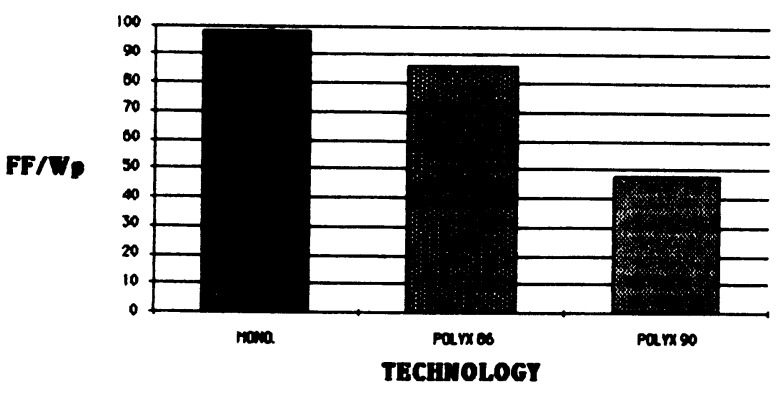

Fig. 6. - Systems prices.

This effect has also a marked effect upon prices of electric $\mathrm{kWh}$ delivered by photovoltaic systems of these types. The example given in figure 7 is based on the same data, for the same type of applications, where reliability and life-expectancy (already greater than 20 years) are decisive parameters and on a real life case involving a generator of a few peak $\mathrm{kW}$ installed in a remote spot in the south of France. It should be recalled that both price levels and facilities (such as self-sufficiency and reduced maintenance) give this type of generator a competitive edge in terms or up-dated overall costs over conventional solutions such as high-capacity chemical batteries, lead-acid batteries and small internal combustion engine generator sets.

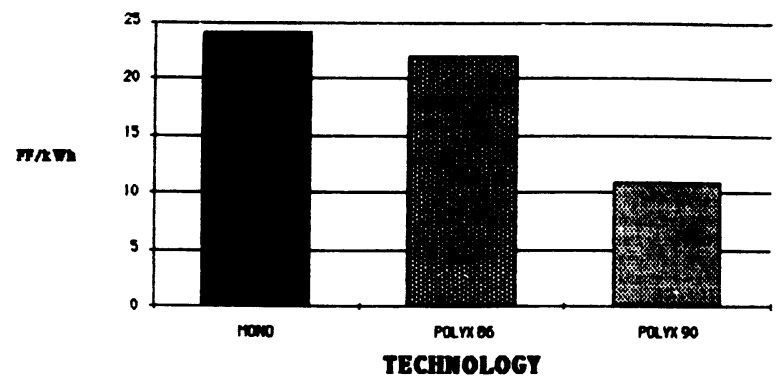

Fig. 7. - kWh prices.

Thus, for the electrification of remote areas and communities, there is no doubt that this technology will hold a growing share of the power-generation market in both the medium and long term, compared with competing technologies such as multicrystalline silicon obtained from ribbon drawing or amorphous silicon. It should be stressed that this is the photovoltaic market segment which has witnessed the most consistent growth in the past decade and, moreover, has the greatest potential for mass growth, due to the tremendous needs to be satisfied, particularly in developing countries.

The Polyx process has the advantage of being able to contribute both directly and through technology transfers to the satisfaction of local market needs. Transfers of technology can be achieved gradually, starting from the encapsulation of cells into modules, followed by local cell production and, where quantities so warrant, by integrated manufacture of ingots and wafers. In the long run, when the process has been industrially validated, local use of initial metallurgical grade silicon with the above processes could become possible. As a matter of fact, all these stages and processes are compatible in size, for plants which have an annual capacity of 1 peak MW or above.

\section{Conclusion.}

The Polyx process has been developed in France in a time span which is comparable or even better than in other countries which have also decided to develop moulded-ingot multicrystalline silicon technologies, i.e. mainly the USA, the FRG, Japan and Italy. The key factors underpinning this success have undoubtedly been : 1) the close cooperation and complementarity of the Marcoussis Laboratories, Photowatt and CNRS and university laboratories, from the initial research stage to development and industrialization of the process and 2) the continued support provided by public authority to these partners. Such a system can only be developed within a long time frame.

The industrial availability of this technology, and its potential development, are major assets in ensuring that the French photovoltaic industry (led by 
Photowatt but also involving downstream photovoltaic systems suppliers) holds a choice position in the world-wide competition to supply electric power and related services to remote areas, for the particular benefit of people who cannot hope to be connected to a central electric grid within a reasonable time. 